\title{
Van bindirme fayı tampon zonunun il afet risk azaltma planı (İRAP) çerçevesinde değerlendirilmesi
}

\author{
Evaluation of the Van thrust fault buffer zone within the framework of the provincial level \\ disaster risk reduction plan (IRAP)
}

\author{
Elif E. ÖZVAN ${ }^{1, a}$, Hasan ÇETİN²,b, Ali ÖZVAN"3,c, İsmail AKKAYA ${ }^{4, d}$ \\ 1 Çukurova Üniversitesi, Fen Bilimleri Enstitüsü, Jeoloji Mühendisliği ABD, Adana \\ 2 Çukurova Üniversitesi, Mühendislik Fakültesi, Jeoloji Mühendisliği Bölümü, Adana \\ ${ }^{3}$ Van Yüzüncü Yıl Üniversitesi, Mühendislik Fakültesi, Jeoloji Mühendisliği Bölümü, Van \\ ${ }^{4}$ Van Yüzüncü Yıl Üniversitesi, Mühendislik Fakültesi, Jeofizik Mühendisliği Bölümü, Van
}

\section{$\ddot{O} z$}

Deprem ihtimali taşıyan illerde, Afet ve Acil Durum Yönetimi Başkanlığı (AFAD) tarafından yürütülen İl Afet Risk Azaltma Planı (IRAP) kapsamında, şehirlerin risk haritası hazırlanmaya başlamıştır. Risk çalışmalarının öncelikli konularından biri de faya bağlı tampon bölgelerin belirlenmesidir. Fayın zeminlerde oluşturduğu deformasyon ve risk, yerleşim alanlarında alan kaybına ve değer kaybına neden olmaktadır. Olası deprem sırasında ortaya çıkacak can ve mal kayıplarının önüne geçilmesi için tampon bölgenin doğru belirlenmesi büyük önem arz etmektedir. Bu çalışmada, Van Gölü doğusunda yer alan eski göl ve akarsu sedimanlarından oluşan Van/Bardakçı bölgesindeki Pleistosen-Holosen yaşlı kil çökellerinin mühendislik özellikleri ve bu zemini kesen bindirme fayının zemin özelliklerini nasıl etkilediği incelenmiştir. 23 Ekim 2011 (Mw=7.1) Van depremine neden olan ve bindirme karakterli Van Fayı'nın tavan ve taban blokları üzerinde yapılan sondajlar ile her iki blok içerisinden alınan zemin numuneleri üzerinde zeminin özellikleri belirlenmiştir. Arazide Standart Penetrasyon Testi (SPT) ve Menard Presiyometre Testi (MPT) yapılmıştır. Aynı zamanda, kil çökellerden örselenmiş ve örselenmemiş (UD) zemin numuneleri alınmış ve laboratuvarda bu numunelerin fiziksel ve mekanik özellikleri belirlenmiştir. Elde edilen sonuçlar değerlendirildiğinde, bindirme fayına yakın kesimlerde tavan bloğunda zemin özelliklerinin taban bloğa nazaran daha düşük dayanım özellikleri gösterdiği tespit edilmiştir. Bindirme türü fay kuşaklarında zemine bağlı afet riski değerlendirildiğinde, tampon bölgenin fayın taban bloğuna göre, tavan bloğunda daha geniş tutulması gerektiği sonucuna ulaşılmıştır.

Anahtar kelimeler: Bindirme fayı, İRAP, Kil zemin, Taban blok, Tampon bölge, Tavan blok, Van

\begin{abstract}
Within the scope of the Provincial Level Disaster Risk Reduction Plan (IRAP) carried out by the Disaster and Emergency Management Presidency (AFAD) in provinces with earthquake probability, the risk map of the cities has been started to be prepared. One of the priority titles of risk studies is determining the buffer zones of faults. The deformation and risk caused by the fault in the settlement area cause loss of area and value on the surface. In order to prevent loss of life and property during a possible earthquake, great importance to determine the buffer zone correctly. In this study, the engineering properties of the Pleistocene-Holocene clay deposits in the Van / Bardakçı region, which consists of old lake and stream sediments located in the east of Lake Van, and how the thrust fault cutting these sediments affects the soils properties was investigated. The characteristics of the soils were determined on the clay samples taken from both the hanging and foot walls by drillings along the Van Fault which caused the 23 October 2011 (Mw = 7.1) Van earthquake. In the field, Standard Penetration Test (SPT) and Menard Pressiometer Test (MPT) were performed. At the same time, disturbed and undisturbed (UD) soil samples were taken from the clay deposits and their physical and mechanical properties were determined in the laboratory. When the results were evaluated, it has been determined that the soil properties of the hanging wall show lower strength properties than the footwall in the zone near to the fault. In disaster risk evaluations, it was concluded that the buffer zone on the hanging wall should be wider than on the foot wall in thrust fault zones.
\end{abstract}

Keywords: Thrust fault, IRAP, Clay soil, Foot wall, Buffer zone, Hanging wall, Van

\footnotetext{
${ }^{*}$ c Ali ÖZVAN; aozvan@yyu.edu.tr, Tel: (0533) 4517973, orcid.org/0000-0001-5459-3989

${ }^{a}$ orcid.org/0000-0002-3355-3432 $\quad{ }^{b}$ orcid.org/0000-0002-8301-5405 d orcid.org/0000-0002-7682-962X
} 


\section{Giriş}

Nüfus artışı ve göçler, hızla büyümekte olan şehir merkezlerinde sürdürülebilir planlama ve uygun arazi kullanım planlarının acil bir şekilde yapılması ihtiyacını doğurmuştur. Bu hızlı gelişim ile birlikte, mühendislik hizmetlerinden yoksun yer seçimleri ve niteliksiz yapılaşma risk dinamiğini giderek arttırmaktadır. Bu nedenlerle sürdürülebilir kentsel gelişmeye sahip olabilmek için stratejiler ve politikalar geliştirilmelidir. Son yıllarda deprem, sel, çı̆̆, taşkın, heyelan gibi doğa olayları sonrasında yaşanan can ve mal kayıplarının azaltılmasına yönelik ülkemizde afet risklerinin belirlenmesi ve azaltılması kapsaminda AFAD başkanlığı tarafından İl Afet Risk Azaltma Planı (İRAP) hazırlık çalışmalarına başlanılmıştır. İRAP bir ilin sahip olduğu afet risklerinin olası etkilerini ortaya koyan bir koordinasyon çalışmasıdır.

Afet denildiğinde de ülkemize akla gelen ilk konu deprem olmaktadır. Depreme bağlı oluşan yapısal hasarlarda bina özelliklerinin önemi kadar yapıların üzerinde yer aldıkları zemin özelliklerinin ve bu zeminlerin deprem esnasındaki tepkilerinin ne denli önemli olduğu son yıllarda meydana gelen depremlerle bir kez daha öne çıkmıştır (Akkaya vd., 2015).

Gerek afet yönetimi gerekse depreme bağlı oluşan hasarların en aza indirgenebilmesi için zemin özelliklerinin ve bu zeminleri etkileyen veya etkileyebilecek unsurların ortaya konması büyük öneme sahiptir. Bu nedenle, deprem gibi dinamik kuvvetlere bağlı oluşabilecek zemin yapısındaki değişimlerin belirlenmesi son derece önem arz etmektedir.

Kohezyonlu ve kohezyonsuz zeminlerde yerleşime esas çalışmalar yapılırken farklı bakış açısı ve değerlendirme yöntemleri kullanılarak olası risk dağılımı ortaya çıkarılmaktadır. Özellikle kohezyonlu zeminlerde birim deformasyon ve zaman arasındaki ilişki lineer olmadığından bu birimler üzerinde inşa edilecek yapılarda bina yüküne bağlı olarak oturmalar gerçekleşebilmekte ve yapıya ciddi ölçüde zarar verebilmektedir. $\mathrm{Bu}$ nedenle yer-yapı ilişkisinin doğru bir şekilde kurulması gerekmektedir. Yapıların oturtulacağ 1 zeminlere ait taşıma gücü ve oturma gibi özelliklerin belirlenmesinde birçok yöntem kullanılmaktadır. Bu yöntemlerin başında da Menard Presiyometre Testi (MPT), Standart Penetrasyon Testi (SPT), Konik Penetrasyon Testi (CPT), plaka yükleme gibi arazi deneyleri ve laboratuvar deneyleri gelmektedir. Özellikle MPT ve SPT zeminlerin yerinde dayanımlarının belirlenmesinde sıkça kullanılmaktadır (Özvan vd., 2018; Özvan, 2019). Genelde laboratuvar verilerine bağlı deneyler için alınan numunelerde oluşabilen örselenme ve numunenin inceleme alanını tam olarak yansitamaması gibi etkenler, laboratuvarda elde edilen ve hesaplamalarda kullanılan parametrelerin doğruluğunu azaltabilmektedir. Ayrıca zemin tabakalarının tamamından örnek almak hem çok pahalı hem de çok zaman aldığından, genelde pek tercih edilmemektedir. Yerinde yapilan deneylerin en büyük avantaj1 zemini örselemeksizin daha gerçekçi ve güvenilir sonuçlar elde edebilmeleridir. Ayrıca yerinde deney yöntem ile istenilen derinlik seviyesinde parametre üretilebilmesi de önemli bir avantajdir.

$\mathrm{Bu}$ çalışmada, Van/Bardakçı bölgesindeki bindirme fayı civarında Van Gölü'nün geçmiş dönemlerdeki su seviye değişimleri sonucu çökelmiş eski göl ve akarsu sedimanlarından oluşan Pleistosen-Holosen yaşlı kil çökellerinin mühendislik özellikleri incelenmiştir. Çalışma kapsamında, 23 Ekim 2011 Van depremine $\left(\mathrm{M}_{\mathrm{w}}=7.1\right)$ neden olan ve bindirme karakterli Van Fayı'nın tavan ve taban blokları üzerinde yapılan sondajlar ile her iki blok içerisindeki zeminlerin özellikleri arazi ve laboratuvar deneyleri ile incelenmiştir. Van Fayından uzaklaştıkça, göl çökellerinin killi seviyelerindeki zemin parametrelerinin nasıl değiştiği belirlenmiştir. Buna göre benzer fay karakteristiklerinin hakim olduğlarda ne gibi zemin özellikleriyle karşılaşılabileceği ve bu özelliklerin nasıl etkilenebileceği hakkında bulgular elde edilmiştir. $\mathrm{Bu}$ veriler 1şığında, bölgedeki killerin mevcut mühendislik özelliklerini etkileyen faktörler dikkate alınarak, afet yönetimi açısından önemli olan risk zonunun belirlenmesi amaçlanmıştır.

$\mathrm{Bu}$ amaçlar doğrultusunda, seçilen inceleme alanında Van Gölü'nden kuzeye doğru yaklaşık 4 km'lik bir hat boyunca eski göl çökelleri içerisindeki kil seviyeleri incelenmiştir (Şekil 1). İlk aşamada inceleme alanı ile ilgili önceki çalışmalar gözden geçirilmiş ve kil seviyesinin yoğun olabileceği 6 farklı sondaj noktası belirlenmiştir (Akın vd., 2015; Akkaya vd., 2019; Özvan vd., 2019). Zeminler içerisinde yaklaşık 15 'er metrelik zemin sondajları planlanmış ve bu sondajlarda her 1.5 metrede bir MPT ve yaklaş1k olarak aynı seviyelerde olacak şekilde SPT deneyleri yapılmıştır. Ayrıca, açılan sondaj kuyularında arazi şartları elverdiğince örselenmiş ve örselenmemiş (UD) zemin numuneleri alınarak, zeminin fiziksel özellikleri (su içeriği, özgül ağılık, birim hacim ağırlık, elek analizi ve kıvam 
limit deneyleri) ve mekanik özellikleri (konsolidasyon ve üç eksenli sıkışma deneyleri) belirlenmiştir. SPT ve MPT parametrelerinin karşılaştırılması için 50 darbeden sonra da SPT deneyine devam edilmiştir. Böylece SPT deneyinde şahmerdanın geri sıçramadığı ve tijlerde eğilmenin olmadığ 1 durumlara kadar $45 \mathrm{~cm}$ 'lik ilerleme sağlanmaya çalışılmıştır.
İnceleme alanında toplam 80 adet UD numunesi alınmıştır. $\mathrm{Bu}$ numuneler laboratuvar ortamında konsolidasyon ve üç eksenli basınç deneylerine tabi tutulmadan önce uygun boyutlarda tüplerden çıkarılmaya çalışılmıştır. Düşük ve yüksek plastisiteli kil ( $\mathrm{CL}$ ve $\mathrm{CH}$ ) sinıfinda olduğu belirlenen killerin konsolidasyon deneyi sonrasında aşırı konsolide oldukları belirlenmiştir.

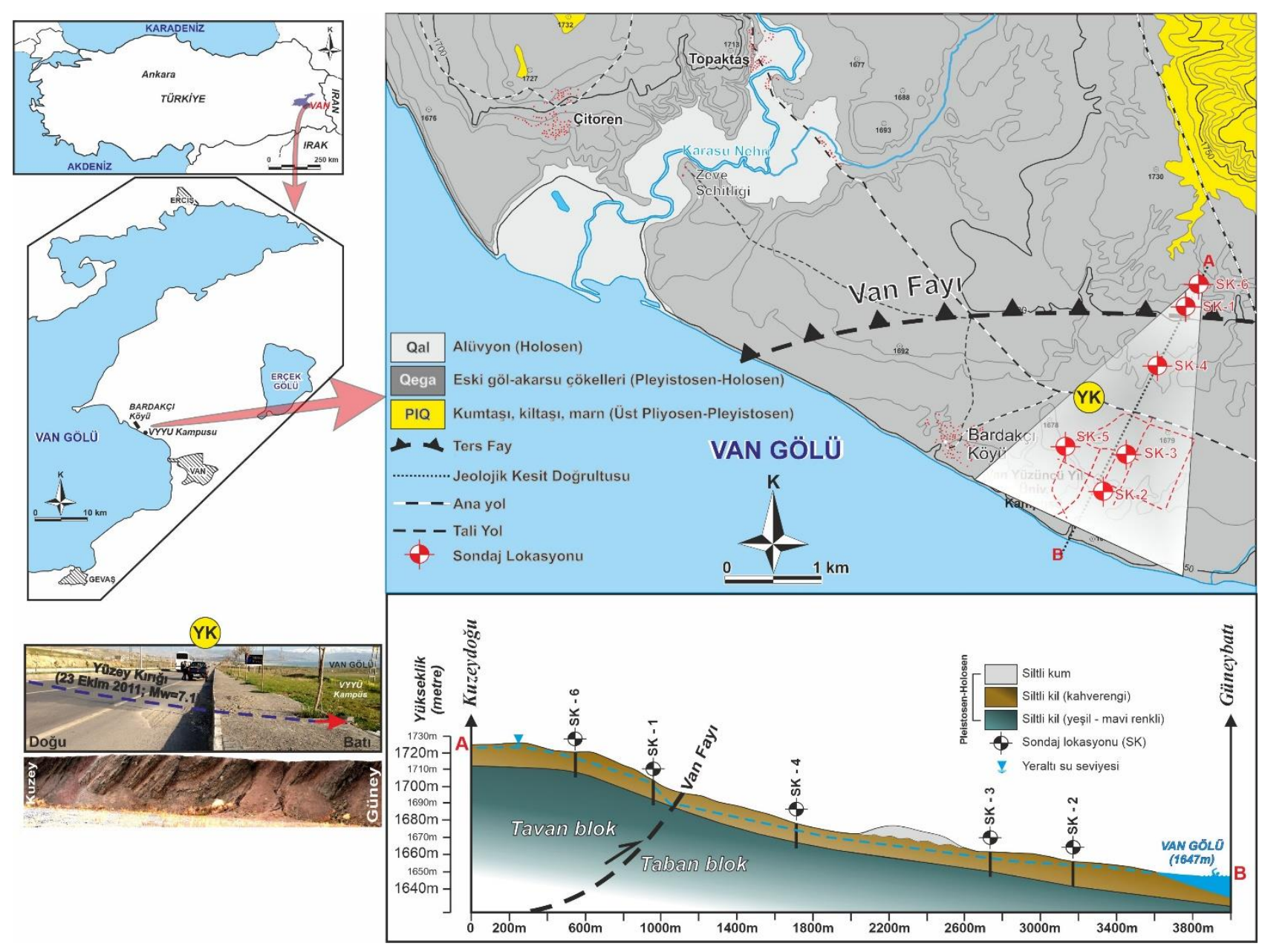

Şekil 1. Çalışma alanının jeolojisi ve KD-GB doğrultulu jeolojik kesiti.

\section{2. Çalışma alanının jeolojisi}

Van Gölü havzası, Arap ile Avrasya levhalarının çarpışması sonucu, Doğu Anadolu Yüksek Platosu (Şengör vd., 1979; Dewey vd., 1986; Şaroğlu vd., 1986) içerisinde Geç Pliyosen'de oluşmaya başlamış ve Kuvaterner başından itibaren etkili olan volkanizmayla birlikte bölge son şeklini almıştır (Degens vd., 1978; Acarlar vd., 1991). Van Gölü çevresindeki temel kaya PaleozoikMesozoyik yaşlı Bitlis Metamorfik Masifidir. Van Gölü'nün doğusunda, Jura kireçtaşları, Geç Kretase ofiyolitleri, Paleosen-Eosen kireçtaşları, Oligosen-Miyosen yaşlı türbidit çökelleri ve eski göl çökelleri yer almaktadır (Bowles, 1988).
İnceleme alanı farklı dönemlerdeki Van Gölü su hareketlerine bağlı olarak çökelen Kuvaterner (Pleyistosen) yaşlı eski göl ve akarsu sedimanlarından oluşmaktadır (Şekil 1). Farklı kalınlıklara ve farklı mühendislik özelliklerine sahip olan bu sedimanlar özellikle Van Gölü’nün doğusunda geniş alanlarda görülmektedir. Van Gölü Havzası, Paleozoyik'ten günümüze kadar farklı yaşlardan kayaç türlerinin yüzeylendiği ve tektonizmanın da etkisiyle oldukça karmaşık stratigrafiye sahip bir alandır. Eski göl çökellerinin toplam kalınlığ yaklaşık 150 metredir (Acarlar vd., 1991). Alanda eski göl çökellerinin yanında eski akarsu çökelleri ile güncel akarsu çökelleri de yer almaktadır (Acarlar vd., 1991; Selçuk, 2003; Koçyiğit, 2013; Akkaya vd., 2015; Akkaya vd., 2019). 
Bu birimler, 23 Ekim 2011 Van depreminde $\left(\mathrm{M}_{\mathrm{w}}=7.1\right)$ hareket eden Van Fayı tarafindan, inceleme alanının kuzeyinde kesilmekte ve inceleme alanının kuzeybatısından Van Gölü'ne kadar uzanmaktadır. Bu birimleri kesen Van Fayı kuzeye eğimli bindirme fayı karakteristiğindedir (Şekil 1).

\section{Arazi çalışmaları}

Çalışma alanında yapılmış önceki sondaj verilerinin yanı sıra bindirme fayının etki alanını incelemek için fayın tavan ve taban bloğunda 6 adet sondaj yapılmış (Şekil 1) ve bölgedeki killi zeminler hem arazi hem de laboratuvar verileriyle birlikte incelenmiştir.

\subsection{Arazi deneyleri}

Yaygın olarak kullanılan arazi deneylerinin başında SPT ve MPT gelmektedir. SPT, zeminin penetrasyon direncini ölçmeyi amaçlayan ve uygulamalarda siklıkla tercih edilen bir yöntemdir. SPT yönteminde otomatik şahmerdan ile deney tüpünün, zemine penetrasyonu sağlanarak SPT-N darbe sayıları elde edilmiş, ardından SPT-N 60 değerleri hesaplanmıştır (Bowles,1988; ASTM D1586/D1586M-18, 2018). SPT testi (Şekil 2a), ASTM standartlarına uygun olarak yapılmıştır (ASTM D1586/D1586M-18, 2018).

MPT ise zemin içerisinde yerleştirilen bir ekipmanla zeminin yanal deformasyon karakteristiklerinin ölçülmesini amaçlar. Bu ekipmanın kullanımı aşamasında karşılaşılan zorluklar, ekipmanın daha fazla geliştirilmesini sağlamış ve böylece "Menard Presiyometresi" adıyla günümüze ulaşmıştır (Menard, 1957).

MPT, özellikle laboratuvar deney numunesi alınamayacak kadar zayıf, bozunmuş zeminlerde ve çok çatlaklı kaya kütlelerinde uygulanmaktadır. MPT ekipmanı okuma ünitesi, sonda, basınçlı hava tüpü ve hortum olmak üzere 4 ana kısımdan oluşmaktadır (Şekil 2b). Sondaj deliğinden içeri gönderilen sonda $44 \mathrm{~mm}$ veya $66 \mathrm{~mm}$ çaplarında olup ana gövde, basınçlı hava hücresi ve basınçlı su hücresi olmak üzere 3 kısımdan oluşmaktadır. Kuyu içerisindeki test seviyesinde sonda, basınçlı hava yardımıyla şişirilir ve sondaj kuyusu çeperlerine 60 saniyede bir basınç uygulanır ve zemin deforme edilmeye çalış1ır. Uygulanan basınç zemini yenerse, kuyu çeperleri deforme olmaya başlar ve basınçlı su hücresine ilave su gönderilmeye başlanır. Sondaya gönderilen su miktarı her 15,30 ve 60 saniyede bir kaydedilir. İşte uygulanan bu basınç düzeyi, zeminin yenilmeye uğradığı basınc1, gönderilen su miktarı ise bu basınç karşısında zeminde elde edilen deformasyon miktarını temsil etmektedir.

$\mathrm{Bu}$ deney sonucunda basınç ve hacim değişimini gösteren presiyometre eğrisi çizilmekte ve bu eğri üzerinden Net Limit Basınç $\left(\mathrm{P}_{\mathrm{L}}\right)$ ve Menard Deformasyon Modülü $\left(\mathrm{E}_{\mathrm{M}}\right)$ değerleri test yapılan her seviye için hesaplanmaktadır (Baquelin vd., 1978; Mair ve Wood, 1987). PL, sondanın hacminin, orijinal zemin boşluğu hacminin iki katına ulaşıldığı basınçtır. $\mathrm{E}_{\mathrm{M}}$ ise, düzeltilmiş basınç-hacim eğrisinin pseudo-elastik kısmının eğiminden hesaplanmaktadır. Bu deney esnasında, ASTM, AFNOR ve APAGEO standartları kullanılmıştır.

Arazi deneylerinden elde edilen veriler yaklaşık 15 'er metrelik 6 adet zemin sondajlarından elde edilmiş olup ilk kuyuda her 1.5 metrede bir MPT yapılırken, aynı seviyelere denk gelecek şekilde eş zamanlı olarak ve yaklaşık 5 metrelik uzaklıkta konumlanmış ikinci kuyuda ise SPT yapılmıştır (Şekil 2). Ayrıca, açılan sondaj kuyularında arazi şartları elverdiğince örselenmiş ve örselenmemiş (UD) zemin numuneleri alınmıştır. Numunelerin hava ile temasını önlemek amaciyla parafin ile kaplanmış ve streç filme sarılmıştır. Laboratuvar ortamında, zeminin fiziksel özellikleri (su muhtevası, özgül ağırlık, birim hacim ağırlık, elek analizi ve kıvam limit deneyleri) ve mekanik özellikleri (konsolidasyon ve üç eksenli sıkışma deneyleri) belirlenmiştir.

\subsection{Laboratuvar deneyleri}

İnce daneli birimlerin fiziksel özelliklerini belirlemek için çalışma alanında farklı noktalarda yapılan 6 adet sondaj çalışmasından alınan örselenmiş numuneler üzerinde ASTM standardına uygun olarak Atterberg limit deneyleri yapılmıştır (ASTM D-4318, 2009).

İnceleme alanındaki ince daneli birimlerin mekanik özelliklerini belirlemek için ASTM standardına göre konsolidasyon deneyleri yapılmıştır (ASTM D-2435, 2009). Deneyde, sabit yük artım süresi 24 saat ve katları ile gerçekleştirilmiştir. Her bir stres artışı, gözeneklerdeki aşırı su basıç̧ları tamamen tükenene kadar sürdürülmüştür. 


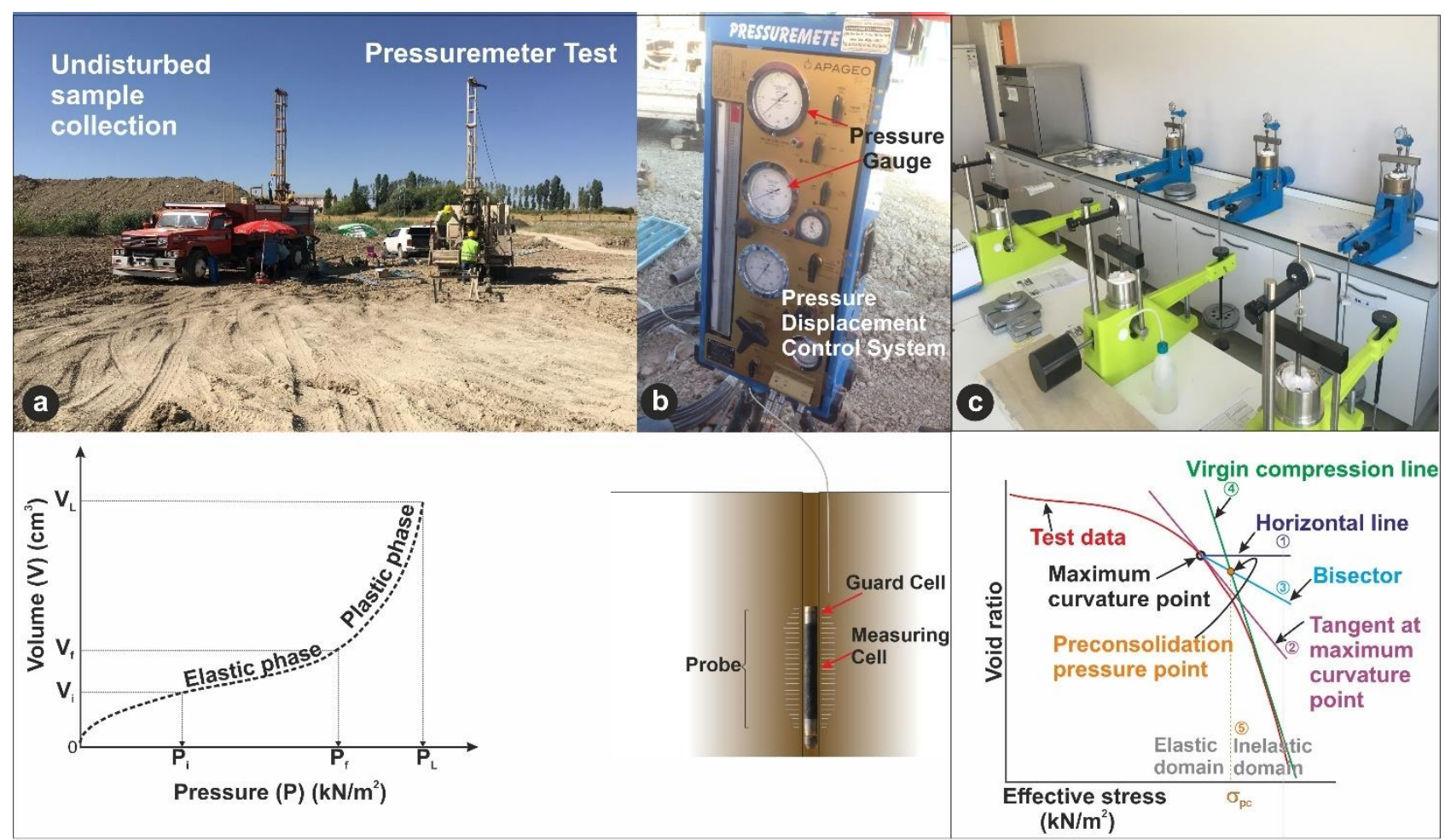

Şekil 2. SPT, PMT ve konsolidasyon ölçümlerine ilişkin görüntüler.

$\mathrm{Bu}$ çalışmaya ait deneylerde minimum numune çap1 $50 \mathrm{~mm}$ ve yüksekliği $20 \mathrm{~mm}$ olan numuneler kullanılmıştır. Deney sırasında boy değişimleri okunabilirliği $0.01 \mathrm{~mm}$ olan komparatörden okunmuştur. Şayet deney, doymuş veya su tablasının altından alınan bir numune üzerinde gerçekleştirilmiş ise, oturma yüklenmesinden kısa bir süre sonra konsolidasyon hücresine su eklenmiştir. Numune, oturma yükünün uygulanmasından kısa bir süre sonra su altında kalmaması halinde ise, buharlaşma nedeniyle numune hacmindeki değişimi önlemek için konsolidasyon cihazı nemli bir pamuk ile kaplanmış ve buharlaşma önlenmiştir. Numune, sabit toplam gerilme artışlarına maruz bırakılmıştır. Deney sonunda bakir bir sıkıştırma eğrisinin eğiminin veya ön konsolidasyon basıncının elde edilmesi için, nihai basınç, ön konsolidasyon basıncının dört katına eşit veya ondan büyük değerlere ulaşacak yüklerden seçilmiştir. Yüklemeler genelde minimum $2.5 \mathrm{kPa}$ gerilme oluşturacak şekilde başlatılmıştır. Boşaltma sırasında deney sonunda kabarmayı en aza indirgemek için, numune oturma yüküne (2.5 $\mathrm{kPa})$ geri döndürülmüştür.

Ön konsolidasyon basınc1 $\left(\sigma_{\mathrm{pc}}\right)$ belirlenmesine yönelik farklı araştırmacılar tarafindan yöntemler geliştirilmiştir (Casagrande, 1936; Tchalenko, 1967; Esu ve Calabresi, 1969). Bu yöntemlerden en çok kullanılanı Casagrande tarafından önerilen yöntem olup (Casagrande, 1936), $\sigma_{\mathrm{pc}}$ 'nin belirlenmesinde kullanılmıştır. $\mathrm{Bu}$ yöntemde, herhangi bir zeminin etkisi altında kaldığı ve ona dokusunun son şeklini veren en büyük efektif gerilme $\left(\sigma^{1}\right)$ değeri, ön konsolidasyon basinc1 olarak tanımlanmaktadır. Ön konsolidasyon basincinin belirlenmesinde, Casagrande (Casagrande, 1936) 'nin geliştirdiği grafik yönteminden elde edilen verilerin kullanılmasıyla çizilen boşluk oranı (e)-efektif gerilme $\left(\sigma^{\prime}\right)$ grafiği üzerinden ön konsolidasyon basinc1 $\left(\sigma_{\mathrm{pc}}\right)$ belirlenmişstir.

Ayrica UD numunelerinden alınan kil zemin üzerinde laboratuvarda konsolidasyonsuz ve drenajsız (UU) üç eksenli sıkışma deneyi yapılmıştır. Düşey yük etkisiyle oluşan kırılma anına denk gelen asal gerilmelerden $\left(\sigma_{1}, \sigma_{3}\right)$ Mohr daireleri çizilerek, Coulomb'un kayma formülüne ait $\mathrm{c}$ ve $\phi$ değerleri elde edilmiştir. Deney ASTM standardına göre yapılmıştır (ASTM D2850, 2015).

\subsection{Ince daneli birimlerin indeks özellikleri}

Çalışmada yapılan sondajlardan örselenmiş ve örselenmemiş (UD) zemin numuneleri alınarak, numunelerin fiziksel özellikleri belirlenmiştir (Tablo 1). Alınan numunelerin dane boyu oranlarına bakıldığında, ince dane boyuna sahip silt ve kil miktarının, toplam dane boyuna oranı \% 80 'den fazla olarak belirlenmiştir. Doğal su içerikleri incelendiğinde, ince dane boyuna sahip zemin numunelerinin genel olarak suya doygun olmadıkları gözlenmektedir. Aynı numunelerin su 
içeriklerine bakıldığında, en yüksek su içeriğinin \% 32.0 , en düşük su içeriğinin ise \% 11.6 olduğu belirlenmiştir. İncelenen numunelerin büyük bir kısmının su içeriklerinin \% 20-24 arasında, ortalama su içeriğinin de \% 21.9 olduğu belirlenmiştir (Tablo 1). Özgül ağırlıkları ve yoğunluk değerine bakıldığında sırasıyla en yüksek özgül ağırlık değeri 2.87, en düşük özgül ağırlık değeri 2.60 , en yüksek yoğunluk $2.14 \mathrm{gr} / \mathrm{cm}^{3}$, en düşük yoğunluk değeri de $1.82 \mathrm{gr} / \mathrm{cm}^{3}$ olarak belirlenmiştir (Tablo 1). Kıvam indisi değerleri incelendiğinde, bu birimlerin Likit Limit (LL) değerleri en büyük \% 88, en küçük \% 25 olarak belirlenirken, Plastik Limit (PL) değerleri en büyük $\% 32$, en küçük $\% 15$ olarak belirlenmiştir. $\mathrm{Bu}$ değerler plastisite abağına yerleştirildiğinde incelenen killi seviyelerin düşük (CL) ve yüksek $(\mathrm{CH})$ plastisiteli kil zemin sinıfinda olduğu belirlenmiştir.

Arazi deneytlerinde SPT darbe sayılarının $\mathrm{N}_{30}$ değerlerinin özellikle faya yakın kesimlerde refü verdiği ( $>50$ darbe $/ 30 \mathrm{~cm}$ ) belirlenmiş̧ir (Tablo 1$)$. Önceki çalışmalardan farklı olarak bu çalışmada, otomatik şahmerdan kullanılarak alınan SPT değerlerinde 50 darbeden sonra SPT verilerinin MPT verileri ile karşılaştırılması için penetrasyona devam edilmeye çalışılmıştır.

İnceleme alanında SPT testleri ile aynı seviyeye karş1lık gelecek şekilde her 1.5 m'de bir MPT testi yapılmaya çalışılmıştır. Arazide yapılan bu test kuyu içi göçme, yeraltı suyu gibi birçok faktörden etkilenebilmektedir. Bu gibi durumlardan dolayı testler sonrasinda elde edilen değerler yorumlandığında bazı seviyelerde Menard presiyometre (elastik) modülü $\left(\mathrm{E}_{\mathrm{M}}\right)$ ve net limit basınç $\left(\mathrm{P}_{\mathrm{L}}\right)$ değerleri hesaplanamamıştır. İnceleme alanında toplamda 33 ayrı seviyede $E_{M}$ ve $P_{L}$ değerleri hesaplanabilmiştir (Tablo 1). Hesaplanan değerlere bakıldığında $\mathrm{E}_{\mathrm{M}}$ değerlerinin 58.7 ile $658.9 \mathrm{kgf} / \mathrm{cm}^{2}$ arasında, $\mathrm{P}_{\mathrm{L}}$ değerlerinin ise 8.7 ile $67.1 \mathrm{kgf} / \mathrm{cm}^{2}$ arasında değiştiği belirlenmiştir. $\mathrm{Bu}$ değerler Menard tarafından verilen (Menard, 1975) tipik $E_{M}$ ve $P_{L}$ değer aralıkları ile karşılaştırıldığında zeminin çok katı-sert kil olduğu görülmektedir. $\mathrm{Bu}$ değerler incelenen zeminlerin fiziksel özellikleri ve SPT-N $\mathrm{N}_{60}$ değerleri ile karşılaştırıldığında sonuçlar arasında bir uyumun olduğu da ayrıca belirlenmiştir.

$\mathrm{Bu}$ çalışmada elde edilen ortalama $\mathrm{E}_{\mathrm{M}}$ değerlerine bakıldığında, en yüksek $E_{M}$ değerlerinin Van Fayı'na yakın alanlarda, en düşük $\mathrm{E}_{\mathrm{M}}$ değerlerinin ise göle yakın alandaki (güneybatı) (SK-2) kuyudan elde edildiği belirlenmiştir (Tablo 1). Bu deneyde de SPT testindeki gibi derinlik arttıkça $E_{M}$ değerlerinin de arttığı görülmektedir.

\section{Verilerin değerlendirmesi}

Çalışma alanındaki ince daneli birimlerde yapılan arazi ve laboratuvar deney sonuçlarının karşılaştırılması ve aralarındaki ilişkilerin ortaya konması için değerlendirmeler yapılmıştır. $\sigma_{\mathrm{pc}}$ ve $\mathrm{E}_{\mathrm{M}}$ değerlerinin derinlik ile değişimlerine bakıldığında genelde derinlik arttıkça $\sigma_{p c}$ ve $E_{M}$ değerlerinin arttığı görülmektedir. Kohezyon (c) değerleri zemin içerisindeki dane boyu, su içeriği gibi özelliklerden etkilendiği için arazi ve laboratuvar verileri arasındaki ilişkiyi elde etmek güç olmaktadır. c değerlerinin derinlik ile değişimlerine bakıldığında genelde derinlik arttıkça c değerlerinin de arttığı görülmektedir. Presiyometre testlerinden elde edilen Net Limit Basınç $\left(\mathrm{P}_{\mathrm{L}}\right)$ ile SPT-N $\mathrm{N}_{60}$ değerleri de genelde derinlik arttıkça artmaktadır.

Van Fayı'nın tavan bloğunda faya yakın noktadaki (SK-1 ve SK-6) zemin verilerine bakıldığında, zemindeki deformasyon yapılarından dolayı bu noktadaki zemin verilerinin etkilendiği belirlenmiştir (Şekil 3).

SK-6 hariç ölçülen ve hesaplanan değerler arasındaki hata payları da oldukça düşük hesaplanmıştır (Şekil 3). Çalışma alanındaki arazi ve laboratuvar deneylerinden elde edilen verilerle hesaplanan regresyon ilişkilerinde benzer sonuçlar elde edilmiştir (Özvan Erdeve, 2019). SK-6 noktasında faya bağlı deformasyonların yüksek olması bu değerlerdeki hata oranlarının da artmasına neden olmuştur. 
Tablo 1. İncelenen killi seviyelere ait bazı fiziksel özellikler ve zemin sınıfları.

\begin{tabular}{|c|c|c|c|c|c|c|c|c|c|c|c|c|c|c|}
\hline \multirow{2}{*}{ SK } & \multirow{2}{*}{$\begin{array}{l}\text { Derinlik } \\
\quad(\mathbf{m})\end{array}$} & \multicolumn{2}{|c|}{ SPT } & \multicolumn{2}{|c|}{$\begin{array}{c}\text { MPT } \\
\left(\mathbf{k g f} / \mathbf{c m}^{2}\right)\end{array}$} & \multicolumn{3}{|c|}{ Atterberg (\%) } & \multirow{2}{*}{$\omega \%$} & \multirow{2}{*}{$\begin{array}{l}\text { Yoğunluk } \\
\left(\mathbf{g r} / \mathrm{cm}^{3}\right)\end{array}$} & \multirow{2}{*}{$\begin{array}{c}\mathrm{c} \\
\left(\mathrm{kg} / \mathrm{cm}^{2}\right)\end{array}$} & \multirow{2}{*}{$\begin{array}{l}\Phi \\
\left({ }^{0}\right)\end{array}$} & \multirow{2}{*}{$\begin{array}{c}\sigma_{\mathrm{pc}} \\
\left(\mathbf{k N} / \mathbf{m}^{2}\right)\end{array}$} & \multirow{2}{*}{$\begin{array}{c}\text { Zemin } \\
\text { Sinıfi }\end{array}$} \\
\hline & & $\mathbf{N}$ & $\mathbf{N}_{60}$ & $\overline{\mathbf{E}_{M}}$ & $\overline{\mathbf{P}_{\mathbf{L}}}$ & $\mathbf{L L}$ & PL & PI & & & & & & \\
\hline 1 & 1.00 & 38 & 21 & 193.1 & 8.7 & 66 & 27 & 39 & 16.4 & 2.11 & 0.19 & 4 & 125.6 & $\mathrm{CH}$ \\
\hline 1 & 2.00 & 73 & 44 & 315.8 & 32.5 & 66 & 27 & 39 & 24.4 & 2.03 & 0.33 & 12 & 127.5 & $\mathrm{CH}$ \\
\hline 1 & 2.75 & 100 & 64 & & & 45 & 20 & 24 & 16.0 & & & & & CL \\
\hline 1 & 4.50 & 100 & 71 & 354.3 & 25.4 & 44 & 20 & 24 & 20.2 & 2.13 & 0.26 & 8 & 147.2 & CL \\
\hline 1 & 5.50 & 105 & 75 & 414.9 & 38.4 & 44 & 18 & 26 & 12.7 & 2.10 & 0.32 & 4 & 138.3 & CL \\
\hline 1 & 6.50 & 108 & 77 & 387.7 & 38.3 & & & & 23.5 & 1.98 & 0.35 & 5 & 137.3 & CL \\
\hline 1 & 7.25 & 102 & 73 & & & 88 & 28 & 60 & 22.3 & & & & & $\mathrm{CH}$ \\
\hline 1 & 8.75 & 91 & 68 & 390.6 & 31.3 & 56 & 26 & 30 & 16.3 & 2.03 & 0.37 & 9 & 196.2 & $\mathrm{CH}$ \\
\hline 1 & 9.75 & 102 & 77 & 342.8 & 21.2 & 60 & 25 & 35 & 21.2 & 2.03 & 0.40 & 11 & 119.7 & $\mathrm{CH}$ \\
\hline 1 & 10.50 & 235 & 176 & & & 36 & 17 & 19 & 12.4 & & & & & CL \\
\hline 1 & 11.25 & 220 & 165 & & & 25 & 19 & 6 & 20.7 & & & & & $\begin{array}{l}\text { CL- } \\
\text { ML }\end{array}$ \\
\hline 1 & 12.50 & 190 & 143 & & & 46 & 19 & 28 & 20.0 & & & & & $\mathrm{CL}$ \\
\hline 2 & 1.00 & 43 & 24 & 149.5 & 15.8 & 46 & 18 & 29 & 17.1 & 1.93 & 0.10 & 4 & 147.2 & CL \\
\hline 2 & 3.50 & 31 & 20 & 126.4 & 16.6 & 58 & 20 & 39 & 31.2 & 1.97 & 0.07 & 6 & 167.8 & $\mathrm{CH}$ \\
\hline 2 & 4.50 & 47 & 33 & 259.0 & 35.3 & 72 & 22 & 49 & 29.3 & 1.82 & 0.12 & 4 & 177.6 & $\mathrm{CH}$ \\
\hline 2 & 5.50 & 31 & 22 & & & 72 & 22 & 49 & 30.7 & & & & & $\mathrm{CH}$ \\
\hline 2 & 6.50 & 30 & 21 & 231.0 & 26.8 & 63 & 22 & 41 & 31.1 & 1.92 & 0.10 & 6 & 186.4 & $\mathrm{CH}$ \\
\hline 2 & 9.00 & 42 & 32 & & & 54 & 21 & 33 & 30.2 & & & & & $\mathrm{CH}$ \\
\hline 2 & 14.00 & 46 & 35 & & & 76 & 22 & 54 & 28.9 & & & & & $\mathrm{CH}$ \\
\hline 3 & 1.00 & 30 & 17 & 202.0 & 21.4 & 76 & 26 & 50 & 23.3 & 1.85 & 0.13 & 6 & 135.4 & $\mathrm{CH}$ \\
\hline 3 & 2.50 & 49 & 31 & 231.8 & 20.5 & 80 & 28 & 52 & 23.9 & 1.92 & 0.10 & 8 & 137.3 & $\mathrm{CH}$ \\
\hline 3 & 4.25 & 80 & 51 & 328.5 & 42.2 & 52 & 21 & 31 & 21.6 & 2.07 & 0.17 & 4 & 206.0 & $\mathrm{CH}$ \\
\hline 3 & 5.50 & 97 & 69 & 345.6 & 31.9 & 50 & 20 & 30 & 22.3 & 2.01 & 0.24 & 7 & 233.5 & $\mathrm{CH}$ \\
\hline 3 & 6.75 & 117 & 83 & 423.6 & 38.5 & 51 & 23 & 28 & 22.8 & 2.02 & 0.24 & 7 & 197.2 & $\begin{array}{l}\text { CL- } \\
\mathrm{CH}\end{array}$ \\
\hline 3 & 7.25 & 42 & 30 & & & 51 & 23 & 28 & 21.4 & 2.09 & 0.26 & 5 & 196.2 & $\begin{array}{l}\text { CL- } \\
\mathrm{CH}\end{array}$ \\
\hline 3 & 8.25 & 82 & 58 & 397.3 & 52.6 & 51 & 23 & 28 & 27.5 & 2.00 & 0.22 & 4 & 206.0 & $\begin{array}{l}\text { CL- } \\
\mathrm{CH}\end{array}$ \\
\hline 3 & 9.00 & 37 & 28 & & & 81 & 29 & 52 & 25.6 & 2.03 & & & 215.8 & $\mathrm{CH}$ \\
\hline 3 & 9.75 & 44 & 33 & & & 64 & 32 & 32 & 27.6 & 1.97 & 0.17 & 1 & 226.6 & $\mathrm{CH}$ \\
\hline 3 & 10.75 & 127 & 95 & 410.8 & 36.8 & 65 & 20 & 44 & 32.0 & 1.97 & & & & $\mathrm{CH}$ \\
\hline 3 & 12.25 & 189 & 142 & 499.7 & 38.9 & 49 & 19 & 30 & 21.1 & 2.10 & 0.32 & 5 & 230.5 & $\mathrm{CH}$ \\
\hline 3 & 13.75 & 20 & 11 & & & 41 & 18 & 23 & 24.0 & 2.02 & 0.42 & 3 & 279.6 & CL \\
\hline 4 & 2.50 & 54 & 34 & & & 65 & 23 & 42 & 22.0 & & & & & $\mathrm{CH}$ \\
\hline 4 & 3.50 & 65 & 47 & 287.8 & 31.0 & 65 & 23 & 42 & 17.4 & 2.14 & 0.32 & 5 & 225.6 & $\mathrm{CH}$ \\
\hline 4 & 4.50 & 103 & 73 & & & 62 & 22 & 39 & 22.2 & & & & & $\mathrm{CH}$ \\
\hline 4 & 5.75 & 99 & 71 & 406.6 & 34.5 & 62 & 22 & 40 & 20.9 & 2.10 & 0.40 & 3 & 230.5 & $\mathrm{CH}$ \\
\hline 4 & 7.00 & 155 & 110 & 479.1 & 40.7 & 56 & 21 & 34 & 20.9 & 2.09 & 0.43 & 4 & 269.8 & $\mathrm{CH}$ \\
\hline 4 & 8.25 & 179 & 128 & 590.7 & 31.4 & 74 & 26 & 48 & 19.8 & 2.08 & & & 294.3 & $\mathrm{CH}$ \\
\hline 4 & 9.50 & 224 & 168 & 658.9 & 38.6 & 49 & 18 & 31 & 19.4 & 2.08 & & & 312.0 & CL \\
\hline 4 & 11.75 & 165 & 124 & & & 36 & 16 & 20 & 12.1 & & & & & CL \\
\hline 5 & 2.50 & 27 & 17 & 132.7 & 16.7 & 26 & 15 & 11 & 19.0 & & & & & CL \\
\hline 5 & 5.50 & 154 & 110 & & & 34 & 20 & 14 & 15.9 & & & & & CL \\
\hline 5 & 6.25 & 100 & 71 & 514.9 & 55.3 & 34 & 18 & 16 & 11.6 & 2.06 & & & 124.6 & CL \\
\hline 5 & 7.25 & 180 & 128 & 620.0 & 51.5 & 34 & 21 & 13 & 18.0 & & & & & CL \\
\hline 6 & 2.25 & 29 & 17 & 58.7 & 9.9 & 48 & 18 & 30 & 26.1 & 2.06 & 0.08 & 4 & 88.3 & $\overline{C L}$ \\
\hline 6 & 3.25 & 39 & 25 & 94.3 & 10.7 & 48 & 18 & 30 & & 1.99 & 0.09 & 3 & 112.8 & CL \\
\hline 6 & 5.50 & 50 & 36 & 96.7 & 10.2 & 46 & 20 & 26 & 23.6 & 2.01 & 0.10 & 4 & 145.2 & CL \\
\hline 6 & 6.50 & 78 & 56 & 173.7 & 23.6 & 53 & 24 & 29 & 27.2 & 1.96 & 0.12 & 4 & 196.2 & $\mathrm{CH}$ \\
\hline 6 & 8.00 & 164 & 117 & & & 54 & 23 & 31 & 18.7 & & & & & $\mathrm{CH}$ \\
\hline 6 & 9.00 & 189 & 142 & 493.0 & 67.1 & 45 & 20 & 25 & 22.6 & 2.04 & & & 233.5 & CL \\
\hline 6 & 10.25 & 197 & 148 & 552.1 & 54.2 & 61 & 21 & 39 & 20.6 & 2.09 & & & 235.4 & $\mathrm{CH}$ \\
\hline
\end{tabular}




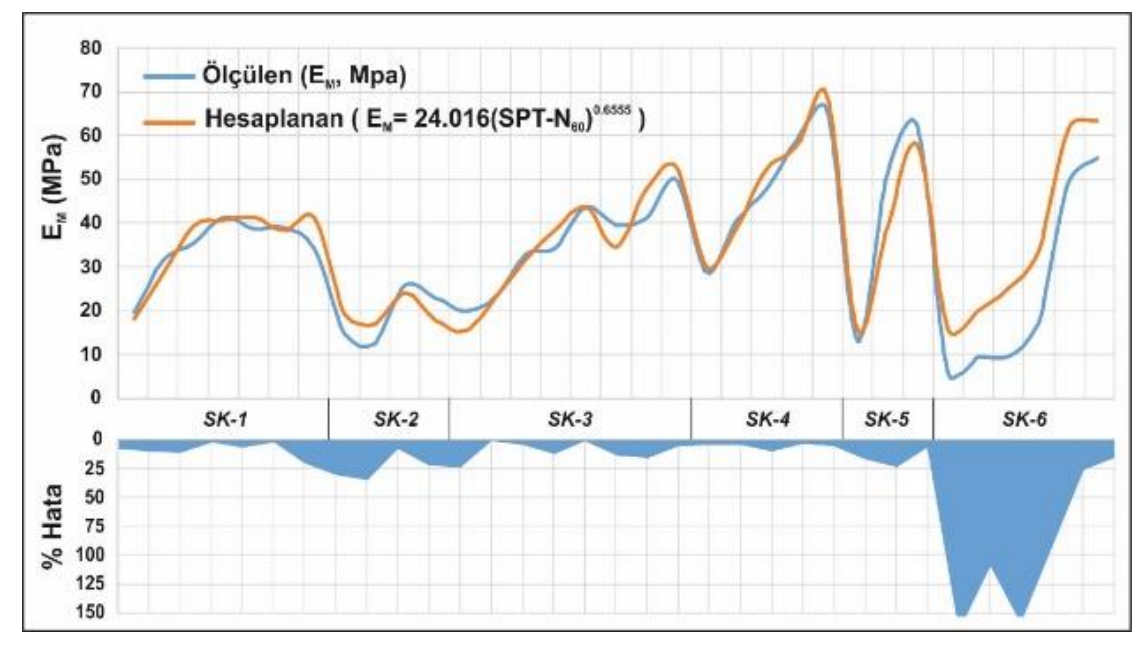

Şekil 3. Ölçülen ve bu çalışmada elde edilen eşitlikten hesaplanan $E_{M}$ değerleri arasındaki grafik ve hata payı dağılımı (Özvan Erdeve, 2019).

\section{Tartışma ve sonuçlar}

Tüm veri grupları değerlendirildiğinde, Van Fayı'nın tavan bloğunda faya yakın noktadaki (SK1 ve SK-6) verilerinin zemindeki deformasyon yapılarından dolayı değişkenlik gösterdiği görülmüsstür. $\mathrm{Bu}$ durum özellikle Afet Risk değerlendirmelerindeki tampon bölgenin belirlenmesinde, bindirme türü deformasyon alanlarında veri setlerinin seçiminin önemini ortaya koymaktadır.

İnceleme alanındaki tüm sondajlardan elde edilen mekanik değerlere bakıldığında, aynı göl çökellerinde farklı noktalarda farklı değerlerin elde edildiği ve derinlik arttıkça mekanik değerlerin de arttığı tespit edilmiş̧ir. Mekanik değerlerin derinlik ile artmasını mevcut düşey yükler de etkilemektedir. $\mathrm{Bu}$ durum, örtü yükü gerilmelerinden dolayı beklenen bir sonuçtur. Çalışma alanında gerek sedimanların düşey yükleri gerekse Van Gölü'nün geçmişte yükselmiş olduğu seviye sonrasında oluşan su yükleri, düşeyde rastlanılan zemin gerilme değişimlerine neden olmuştur. Sedimantasyon ile birlikte gelişen karbonat çökelimi, katyon değişimi, silikat bozunumu gibi biyo-jeokimyasal olaylarla kil tanelerinin suda çözünmüş halde bulunan karbonat, soda ve tuz ile bağlanması ihtimali de bölgedeki farklı mekanik sonuçların nedenlerinden birisi olabilir. Fakat aynı göl çökelleri içerisinde kuzeyden güneye doğru gidildikçe yatayda gözlenen değişimler için literatürde rastlanılan bir açıklama bulunmamaktadır. 2011 Van depremi sonrasındaki bazı çalışmalarda (Akinci ve Antonioli, 2013), Van fayından uzaklaştıkça stres dağılımının azaldığ 1 belirtilmiştir. Bu gerilmelerin de doğal olarak zemin hafizasına kaydedildiği, gerilmelere neden olan yüzey faylanmaları sırasında faydan uzaklaştıkça ön konsolidasyon basıncının azaldığı da bilinmektedir (Çetin, 1997; Çetin, 2000). Literatürdeki bu çalışmalar inceleme alanındaki veri dağılımı ile karşılaştırıldığında fay düzleminden uzaklaşıldığında zeminden elde edilen gerilme değerlerinin azalmasının doğal olduğunu ve çalışma alanındaki zeminlerin yatay yöndeki değişimlerinin bu etkenler ile açıklanabileceğini göstermektedir. Bu farklılıklar Van Bindirme Fayı'nın oluşturduğu gerilmenin, zeminin mekanik özellikleri üzerinde daha etkili olduğu tezini güçlendirmiştir.

Fay düzlemi bindirme karakterli olduğundan taban bloğa yakın noktalarda (SK-4 ve SK-5) sıkışmaya bağlı olarak daha yüksek mekanik özellikler elde edilmiştir. Bu çalışmada elde edilen ortalama SPT$\mathrm{N}_{60}$ darbe sayılarına ve $\mathrm{E}_{\mathrm{M}}$ değerlerine bakıldığında, en yüksek değerler taban blokta Van Fayına yakın alanlarda, en düşük değerler ise göle yakın alandaki (SK-2) noktasından elde edilmiştir. Özellikle tavan ve taban blokta fay düzleminde yakın noktalardaki deney sonuçlarının mevcut düşey örtü yükü gerilmeleri dışında tektonik gerilmelerden etkilendiği bu çalışmada ilk defa ortaya konmuştur.

Bindirme faylarında tavan blokta zemin özelliklerinin taban bloktan daha düşük değerlere sahip olduğu ve bu zonun tavan blok üzerinde yaklaşık fay çizgisinden 500m'lik bir uzaklığa kadar zemini etkilediği belirlenmiştir (Şekil 4). Taban blokta ise fayın oluşturduğu gerilmelerin zeminin mekanik özelliklerini daha da arttırdığı belirlenmiştir. Bu durum, bindirme türü faya bağl1 yer hareketinin zemini deforme etme derecelerinin tavan bloğu üzerinde daha fazla olacağını göstermektedir. 
Elde edilen sonuçlar değerlendirildiğinde, Afet risk değerlendirmelerinde bindirme türü faylar için tampon bölge belirlenirken "Yerleşime Uygun Olmayan Alan"1n belirlemesinde çizilen tampon bölge için tavan ve taban blokta farklı genişliklerin uygulanmasının daha doğru olacağı düşünülmektedir. Özellikle tavan blokta fay düzlemi gerisinde oluşan deformasyon yapıları yüzeye yakın noktalarda daha fazla zemin özelliklerini etkilemekte ve zeminin mekanik parametrelerinin düşmesine neden olmaktadır. Bu zonun doğru belirlenmesi hem arazi kayıplarına bağlı olarak ortaya çıkacak olan maddi kaybın önüne geçecek hem de Afet Risk Azaltma Planı (İRAP) çalışmalarında doğru bir yönlendirme sağlayacaktır.

Bindirme/Ters fay etki alanındaki arazi ve laboratuvar deneylerinde gözlenen farklı fiziksel ve mekanik özelliklerin diğer fay türleri için de incelenmesi, bu tür çalışmaların sonuçlarının geliştirilmesi İRAP açısından son derece önemlidir.



Şekil 4. Van Fayında zeminin mekanik özelliklerinin düşük (kırmızı) ve yüksek (mavi) olduğu bölgeler. 


\section{Kaynaklar}

Acarlar, M., Bilgin, Z. A., Erkal, T., Güner, E., Şen, A.M., Umut, M., Elibol, E., Gedik, İ., Hakyemez, Y. ve Uğuz, M.F. (1991). Van Gölü doğu ve kuzeyinin jeolojisi. MTA Raporu, Ankara, No: $9469,94 \mathrm{~s}$.

AFNOR. (2000). NF P 94-110-1: Sols, Reconnaissances et essais-Essai pressiometrique Menard. French Standard, Edited by afnor, Paris-La defense, Publisher Location.

Akın, K. M., Akın, M., Akkaya, İ., Özvan, A., Üner, S., Selçuk, L. ve Tapan, M. (2015). Mikrobölgeleme çalışmasına altlık oluşturmak üzere Van Yüzüncü Y1l Üniversitesi kampüs zemininin dinamik özelliklerinin belirlenmesi. Jeoloji Mühendisliği Dergisi, 39(1), 1-26. https://doi.org/10.24232/jeoloji-muhendisligidergisi.295346

Akinci, A. and Antonioli, A. (2013). Observations and stochastic modelling of strong ground motions for the 2011 October $23 \mathrm{Mw} 7.1 \mathrm{Van}$, Turkey. Earthquake. Geophys. J. Int., 192(3), 1217-1239. htttps://doi.org/10.1093/gji/ggs075

Akkaya, İ., Özvan, A., Tapan, M., and Şengül, M. A. (2015). Determining the site effects of 23 October 2011 earthquake (Van province, Turkey) on the rural areas using HVSR microtremor method. Journal of Earth System Science, 124(7), 1429-1443.

Akkaya, İ., Özvan, A., and Özvan Erdeve, E. (2019) A new empirical correlation between pressuremeter modules (Em) and shear wave velocity (Vs) for clay soils. Journal of Applied Geophysics, 171. https://doi.org/10.1016/j.jappgeo.2019.103865

Akkaya, İ. and Özvan, A. (2019). Site characterization in the Van settlement (Eastern Turkey) using surface waves and HVSR microtremor methods. Journal of Applied Geophysics, 160, 157-170. https://doi.org/10.1016/j.jappgeo.2018.11.009

APAGEO. (2006). Menard Pressuremeter (G Type) operating instructions, 2006 edition.

ASTM. (2010). Standard Test Method for Liquid Limit, Plastic Limit and Plasticity Index of Soils. ASTM D4318-10el, West Conshohocken, PA.

ASTM. (2020). Standard Test Method for OneDimentional Consolidation Properties of Soils, ASTM D2435 / D2435M-11, West Conshohocken, PA.

ASTM D 2850. (2015). Standard Test Method for Unconsolidated-Undrained Triaxial Compression Test on Cohesive Soils. ASTM D2850 - 15, West Conshohocken, PA.
ASTM D1586/D1586M-18. (2018). Standard Test Method for Standard Penetration Test (SPT) and Split-Barrel Sampling of Soils, ASTM D1586/D1586M-18, West Conshohocken, PA.

Baquelin, F., Jezequel, J. F., and Shields, D. H. (1978). The pressuremeter and foundation engineering. Clausthal-Zellerfeld: Trans Tech Publications, Germany, 617 p.

Bowles, J. E. (1988). Foundation Analysis and Design. 4th Edition. McGraw Hill, 1023 p.

Casagrande, A. (1936). The Determination of the PreConsolidation Load and its Partical Significance. Discussion D-34, Proceeding of the First International Conference on Soil Mechanics and Foundation Engineering, 3, (pp. 60-64). Cambridge: Massachusetts.

Cetin, H. (1997). How did the Meers fault scarp form? paleoearthquake or aseismic creep? a soil mechanical perspective. Engineering Geology, Elsevier, 47, 289-310. https://doi.org/10.1016/S0013-7952(97)00028-8

Cetin, H. (2000).An experimental study of soil memory and preconsolidation adjacent to an active tectonic structure: the Meers fault, Oklahoma, USA. Engineering Geology, Elsevier, 57, 169$178 . \quad$ https://doi.org/10.1016/S00137952(00)00026-0

Degens, E. T., Wong, H. K., Kurtman, F. and Finckh, P. (1978). Geological development of Lake Van: summary. 1n: the geology of Lake Van, (editors: Degens, e.t., Kurtman F.). The Mineral Researchand Exploration Institute of Turkey (MTA), Publication No:169, 134-146.

Dewey, J. F., Hempton, M. R., Kidd, W. S. F., Şaroğlu, F., and Şengör, A. M. C. (1986). Shortening of continental lithosphere: the neotectonics of Eastern Anatolia a young collision zone. Geol. Soc. Spec. Publ., 19, 1-36. https://doi.org/10.1144/GSL.SP.1986.019.01.01

Esu, F. and Calabresi, G. (1969) Slope stability in an overconsolidated clay. In: Proceedings of 7 th international conference on soil mechanics and foundation engineering, Mexico City, Mexico, 2, 555-563.

Koçyiğit, A. (2013). New field and seismic data about the intraplate strike-slip deformation in Van region, East Anatolian plateau, E. Turkey. Journal of Asian Earth Sciences, 62, 586-605. https://doi.org/10.1016/j.jseaes.2012.11.008

Mair, R. J. ve Wood, D. M. (1987). Pressuremeter testing methods and interpretation. CIRIA, ISSN:0-408-02434-8. 
Menard, L. (1957). An apparatus for measuring the strength of soils in place. Thesis, University of Illinois.

Menard, L. (1975). The Menard Pressuremeter: Interpretation and Application of Pressuremeter Test Results to Foundation Design, D.60.AN. Sols Soils, (26), 5-43.

Özvan, A., Akkaya, İ., and Tapan, M. (2018). An approach for determining the relationship between the parameters of pressuremeter and SPT in different consistency clays in Eastern Turkey. Bulletin of Engineering Geology and The Environment, 77, 1145-1154. https://doi.org/10.1007/s10064-017-1020-9

Özvan Erdeve, E. (2019). Van/Bardakçı bölgesi zeminlerinde arazi ve laboratuvar deneyleri arasındaki ilişkilerin jeoteknik ve istatistiksel açıdan incelenmesi. Doktora Tezi, Çukurova Üniversitesi Fen Bilimleri Enstitüsü, Adana.

Özvan, A., Özvan Erdeve, E., Akkaya İ., Akın M., and Akın M. (2019). A study of the relationship between The Pressuremeter Modulus and The Preconsolidation Pressure around a thrust fault. Environmental Earth Sciences, 78, 596. https://doi.org/10.1007/s12665-019-8597-1

Şengör, A. M. C. and Kidd, W. S. F. (1979). Postcollisional tectonics of The Turkish-Iranian plateau and a comparison with Tibet. Tectonophys. 55, 361-376. https://doi.org/10.1016/0040-1951(79)90184-7

Şaroğlu, F. ve Yılmaz, Y. (1986). Doğu Anadolu'da neotektonik dönemdeki jeolojik evrim ve havza modelleri. MTA Dergisi, 107, 73-94.

Selçuk, L. (2003). Yüzüncü Y1l Üniversitesi Zeve Kampüsü yerleşim alanının mühendislik jeolojisi. Yüksek Lisans Tezi, Yüzüncü Y1l Üniversitesi Fen Bilimleri Enstitüsü, Van.

Tchalenko, J.S. (1967) The influence of shear and consolidation on the microscopic structure of some clays. Ph D Thesis, University of London, London, UK. 